\title{
The Utility of Caco-2 cells in Isolation of Enteroviruses from Environmental and Clinical Material
}

\author{
MAGDALENA WIECZOREK*, AGNIESZKA CIĄĆKA, AGNIESZKA WITEK \\ and BOGUMIŁA LITWIŃSKA. \\ National Institute of Public Health - National Institute of Hygiene, Department of Virology, Warsaw, Poland
}

Submitted 2 September 2013, revised 30 October 2013, accepted 16 November 2013

\begin{abstract}
The work presented here demonstrates the utility of Caco-2 cells in the isolation of enteroviruses (EVs) from environmental and clinical materials. Thirty-two samples of cerebrospinal fluid positive in Pan-entero RT-PCR were taken for EV strain isolation in cell culture. Out of the 32 samples analysed, $22(68.75 \%)$ were positive for enteroviruses by isolation in Caco-2 cells, and 10 (31.25\%) were positive by isolation in RD cells. High viral titre in clinical specimens resulted in rate increase for isolation in Caco-2 cells and RD cells ( $87.5 \%$ and $50 \%$, respectively). Also, the probability of isolation of enteroviruses from sewage in Caco- 2 cells was 20 times higher that in RD cells. We proved that Caco-2 cells were more effective than $\mathrm{RD}$ cells in enterovirus isolation, irrespective of the material used in the inoculation process.
\end{abstract}

Ke y words: Caco-2 cells, cerebrospinal fluid, enteroviruses, sewage

\section{Introduction}

Enteroviruses (EVs) are members of the Picornaviridae family, a large and diverse group of small RNA viruses characterized by a single-positive-strand genomic RNA. They affect millions of people worldwide each year, and are often found in the respiratory secretions and stool of an infected person. Infection can result in a wide variety of symptoms ranging from mild respiratory illness (common cold), through hand, foot, and mouth disease, acute haemorrhagic conjunctivitis, aseptic meningitis, and myocarditis, to severe neonatal sepsis-like disease and acute flaccid paralysis. (Tapparel, 2012)

The classic method for diagnosis of infection with EVs has been virus isolation by cell culture from stool samples, throat swabs, or cerebrospinal fluid (CSF). Cell culture is still the best method for determining the occurrence of infectious viruses in environment, as well. Viral isolation is possible in a variety of cell lines; however, no single cell line is optimal for all EVs.

PCR methods for detecting enteroviruses have been developed during the past decade. Many studies have shown that PCR is more sensitive and rapid than virus isolation for the diagnosis of enteroviral infection. Although detection by PCR reveals the presence of viral RNA, it does not indicate the infectivity of the virus.
The determination of viral infectivity is important especially in environmental monitoring. The detected genomic material may be present in otherwise defective virus particles that are not able to bind to or replicate in the host cells. Knowing if a virus is infectious is important from a public health perspective to determine if there is a public health concern. The infectivity of viruses may be determined with the use of cell cultures, such as Caco-2 and RD (Terletskaia-Ladwig et al., 2008; Sedmak et al., 2005). Caco-2 cell line is a continuous line of heterogeneous human epithelial colorectal adenocarcinoma cells. It has been found that Caco-2 cells support the growth of many viruses, including enteroviruses, rotaviruses, adenoviruses, and astroviruses (Hamza 2011; Pinto et al., 1995). However, WHO recommended $\mathrm{RD}$ cells for isolation of polioviruses and other enteroviruses. Most of the enterovirus serotypes have been propagated in $\mathrm{RD}$ cells, but in practice isolation from clinical and environmental material is often unsuccessful (Lipson et al., 1988; Witek et al., 2011).

The present study was conducted to obtain information about the utility of Caco- 2 cell in the isolation of enteroviruses from environmental (sewage) and clinical samples (CSF). CSF is not a simple material for enterovirus strains isolation, because the enterovirus load is lower than in faeces during enteroviral meningitis, and also is rich in replication-defective particles. Sewage is

\footnotetext{
* Corresponding author: M. Wieczorek, Chocimska 24 Str., 00-791 Warsaw, Poland; phone: +48 225421 230, fax: +48 22 54 385; e-mail: mrechnio@pzh.gov.pl
} 
a heterogeneous material rich in factors such as metals, humic acids, and other organic matter which can be toxic for cells. Our goal was to compare EVs' isolation from this material in Caco- 2 and $\mathrm{RD}$ cells.

\section{Experimental}

\section{Materials and Methods}

CSF samples. Cerebrospinal fluid samples were obtained in 2011 and 2012 from patients with suspicion of enteroviral infection, and sent to the Laboratory of Virology in the National Institute of Health for viral diagnostics. Thirty-two samples of CSF positive in Pan-entero RT-PCR were taken for EV strain isolation in cell culture. These samples were divided into two groups: strong positive - with intensive band after RT-PCR reaction and weak positive - with not clearly seen band. A volume of $200 \mu \mathrm{l}$ of cerebrospinal fluid was inoculated into tubes with $\mathrm{RD}$ and Caco-2 cells. The tubes were incubated at $37^{\circ} \mathrm{C}$. Each specimen underwent two passages in RD and Caco- 2 cells. Samples demonstrating viral cytopathic effect (CPE) were identified by neutralization assay using specific antisera (National Institute of Public Health and the Environment, the Netherlands).

Sewage samples. Samples of raw sewage were processed according to the protocol described earlier (Zurbriggen et al., 2008). Tubes with monolayer of $\mathrm{RD}$ and Caco- 2 cells in maintenance medium were inoculated with $100 \mu$ l of sewage sample; before inoculation, samples were incubated with different concentrations of trypsin (from 0 to $50 \mu \mathrm{g} / \mathrm{ml}$ ) for different times (from $0 \mathrm{~min}$ to $2 \mathrm{~h}$ ) at $37^{\circ} \mathrm{C}$ and next were added to those tubes. Cytopathic effects were read daily for 7 days, and two passages were performed. Supernatant fluids from samples demonstrating viral CPE were used for the RT-PCR detection to confirm the presence of the virus. Four independent experiments were performed.

RNA extraction and RT-PCR. Viral RNA was extracted from $140 \mu$ lof CSF, cell culture supernatant or concentrated sewage using spin columns (Qiagen) following the manufacturer's instructions. RT-PCR was carried out using Pan-enterovirus primers for enterovirus detection based on the WHO manual (WHO, 2004). This set of primers produces a product of $114 \mathrm{bp}$ and has been designed to detect and amplify a genome segment present at the 5'-UTR of the enterovirus genomes. RT-PCR amplification was performed: one cycle of reverse transcription at $45^{\circ} \mathrm{C}$ for $20 \mathrm{~min}$; one cycle of denaturation at $94^{\circ} \mathrm{C}$ for $2 \mathrm{~min} ; 30$ cycles of denaturation at $94^{\circ} \mathrm{C}$ for $30 \mathrm{~s}$; annealing at $55^{\circ} \mathrm{C}$ for $30 \mathrm{~s}$; elongation at $70^{\circ} \mathrm{C}$ for $30 \mathrm{~s}$ followed by one cycle of elongation at $70^{\circ} \mathrm{C}$ for $7 \mathrm{~min}$. Reaction mixtures were then held at $4^{\circ} \mathrm{C}$. Amplification products were analysed in $2 \%$ agarose gels, GelRed-stained, and examined under a UV DNA trans-illuminator.

Statistical analysis. Received data were analysed with Statgraphics for Windows, Centurion, v.XV. StatPointTech.Inc. USA. Simple linear regression and multiple regression model was used to estimate relationships among variables.

\section{Results}

A total of 177 cerebrospinal fluid samples were obtained in 2011 (59) and 2012 (118) from patients with suspicion of enteroviral infection, and sent to the Laboratory of Virology in the National Institute of Health for viral diagnosis. Of 177 CSF samples, 85 (48\%) samples were positive in RT-PCR reaction (36\% in 2011 and $60 \%$ in 2012). Thirty-two CSF samples were selected from all positive samples. These samples were divided into two groups: strong positive (16) - with intensive band after RT-PCR reaction and weak positive (16) - with not clearly seen band. A volume of $200 \mu \mathrm{l}$ of cerebrospinal fluid was inoculated into tubes with RD and Caco-2 cells according to WHO procedures. Out of the 32 samples analysed, 22 (68.75\%) were positive for enteroviruses by isolation in Caco- 2 cells, and $10(31,25 \%)$ were positive by isolation in $\mathrm{RD}$ cells (Table I). There were two positive isolations in RD cells $(12.5 \%)$ in the group of weak-positive samples unlike isolation in Caco-2 cells - 50.0\% (8) positive results. The best results were obtained in the group of strongpositive samples (intensive band) isolated in Caco-2 cells $-87.5 \%$ positive results. However, positive isolation from this group of material in $\mathrm{RD}$ cells was much lower (50.0\%). Serotyping revealed the predominance of echovirus 6 (E6), followed by E11.

Samples of sewage were collected from several locations around Poland in 2011. Samples were evaluated

Tabele I

Enteroviruses isolation from CSF in RD and Caco-2 cells.

\begin{tabular}{|l|c|c|c|c|c|c|}
\hline \multicolumn{1}{|c}{$\begin{array}{c}\text { RT-PCR } \\
\text { Pan-entero results }\end{array}$} & $\begin{array}{c}\text { No. } \\
\text { of samples }\end{array}$ & \multirow{2}{*}{$\begin{array}{c}\text { Total no. } \\
\text { of samples }\end{array}$} & $\begin{array}{c}\text { RD } \\
\text { positive isolation }\end{array}$ & $\begin{array}{c}\text { Total RD } \\
\text { positive isolation }\end{array}$ & $\begin{array}{c}\text { Caco-2 } \\
\text { positive isolation }\end{array}$ & $\begin{array}{c}\text { Total Caco-2 } \\
\text { positive isolation }\end{array}$ \\
\cline { 1 - 1 } Strong-positive & 16 & \multirow{2}{*}{$32(100 \%)$} & $8(50.0 \%)$ & \multirow{2}{*}{$10(31.25 \%)$} & $14(87.5 \%)$ & \multirow{2}{*}{$22(68.75 \%)$} \\
\cline { 1 - 1 } & & 16 & $2(12.5 \%)$ & & $8(50.0 \%)$ & \\
\hline
\end{tabular}


Table II

Sewage samples analysis for enteroviruses in RD cells.

\begin{tabular}{|c|c|c|c|c|c|c|c|}
\hline & \multicolumn{5}{|c|}{ Incubation time } & \multirow{2}{*}{$\begin{array}{l}\text { No of positive } \\
\text { results }\end{array}$} \\
\hline & & $0^{\prime}$ & $10^{\prime}$ & $30^{\prime}$ & $1 \mathrm{~h}$ & $2 \mathrm{~h}$ & \\
\hline \multirow{9}{*}{ 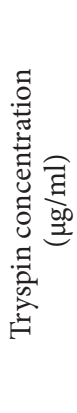 } & 0 & 0000 & 0000 & 0000 & 0000 & 0000 & 0 \\
\hline & & $\mathrm{P}=0$ & $\mathrm{P}=0$ & $\mathrm{P}=0$ & $\mathrm{P}=0$ & $\mathrm{P}=0$ & $\mathrm{P}=0$ \\
\hline & 5 & 0000 & 0000 & 0000 & 0000 & +000 & 1 \\
\hline & & $\mathrm{P}=0$ & $\mathrm{P}=0$ & $\mathrm{P}=0$ & $\mathrm{P}=0$ & $\mathrm{P}=0.25$ & $\mathrm{P}=0.05$ \\
\hline & 10 & 0000 & 0000 & 0000 & 0000 & 0000 & 0 \\
\hline & & $\mathrm{P}=0$ & $\mathrm{P}=0$ & $\mathrm{P}=0$ & $\mathrm{P}=0$ & $\mathrm{P}=0$ & $\mathrm{P}=0$ \\
\hline & 50 & 0000 & +000 & 0000 & 0000 & 0000 & 1 \\
\hline & & $\mathrm{P}=0$ & $\mathrm{P}=0.25$ & $\mathrm{P}=0$ & $\mathrm{P}=0$ & $\mathrm{P}=0$ & $\mathrm{P}=0.05$ \\
\hline & No of positive results & $\begin{array}{c}0 \\
\mathrm{P}=0\end{array}$ & $\begin{array}{c}1 \\
\mathrm{P}=0.06\end{array}$ & $\begin{array}{c}0 \\
P=0\end{array}$ & $\begin{array}{c}0 \\
P=0\end{array}$ & $\begin{array}{c}1 \\
\mathrm{P}=0.06\end{array}$ & \\
\hline
\end{tabular}

P - propability; 0 - lack of cytopathic effect; + - characteristic enterovirus cytopathic effect.

Table III

Sewage samples analysis for enteroviruses in Caco-2 cells.

\begin{tabular}{|c|c|c|c|c|c|c|c|}
\hline & \multicolumn{5}{|c|}{ Incubation time } & \multirow{2}{*}{$\begin{array}{l}\text { No of positive } \\
\text { results }\end{array}$} \\
\hline & & $0^{\prime}$ & $10^{\prime}$ & $30^{\prime}$ & $1 \mathrm{~h}$ & $2 \mathrm{~h}$ & \\
\hline \multirow{5}{*}{ 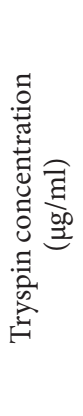 } & 0 & $\begin{array}{c}+++0 \\
\mathrm{P}=0.75\end{array}$ & $\begin{array}{c}+++0 \\
\mathrm{P}=0.75\end{array}$ & $\begin{array}{c}+++0 \\
\mathrm{P}=0.75\end{array}$ & $\begin{array}{c}+000 \\
\mathrm{P}=0.25\end{array}$ & $\begin{array}{c}++00 \\
\mathrm{P}=0.50\end{array}$ & $\begin{array}{c}12 \\
\mathrm{P}=0.60\end{array}$ \\
\hline & 5 & $\begin{array}{c}+000 \\
\mathrm{P}=0.25\end{array}$ & $\begin{array}{c}+++0 \\
\mathrm{P}=0.75\end{array}$ & $\begin{array}{c}++00 \\
\mathrm{P}=0.50\end{array}$ & $\begin{array}{c}++00 \\
\mathrm{P}=0.50\end{array}$ & $\begin{array}{c}+++0 \\
\mathrm{P}=0.75\end{array}$ & $\begin{array}{c}11 \\
\mathrm{P}=0.55\end{array}$ \\
\hline & 10 & $\begin{array}{c}+++0 \\
\mathrm{P}=0.75\end{array}$ & $\begin{array}{c}+++0 \\
\mathrm{P}=0.75\end{array}$ & $\begin{array}{c}+++0 \\
\mathrm{P}=0.75\end{array}$ & $\begin{array}{c}+000 \\
\mathrm{P}=0.25\end{array}$ & $\begin{array}{c}++00 \\
\mathrm{P}=0.50\end{array}$ & $\begin{array}{c}12 \\
\mathrm{P}=0.60\end{array}$ \\
\hline & 50 & $\begin{array}{c}+000 \\
\mathrm{P}=0.25\end{array}$ & $\begin{array}{c}+000 \\
\mathrm{P}=0.25\end{array}$ & $\begin{array}{c}+++0 \\
\mathrm{P}=0.75\end{array}$ & $\begin{array}{c}++00 \\
\mathrm{P}=0.50\end{array}$ & $\begin{array}{c}+000 \\
\mathrm{P}=0.25\end{array}$ & $\begin{array}{c}8 \\
\mathrm{P}=0.40\end{array}$ \\
\hline & No of positive results & $\begin{array}{c}8 \\
\mathrm{P}=0.50\end{array}$ & $\begin{array}{c}10 \\
\mathrm{P}=0.62\end{array}$ & $\begin{array}{c}11 \\
\mathrm{P}=0.69\end{array}$ & $\begin{array}{c}6 \\
\mathrm{P}=0.38\end{array}$ & $\begin{array}{c}8 \\
\mathrm{P}=0.50\end{array}$ & \\
\hline
\end{tabular}

P - propability; 0 - lack of cytopathic effect; + - characteristic enterovirus cytopathic effect.

by RT-PCR assay for the presence of enteroviruses. Positive samples were pooled and isolated in Caco-2 and RD cells. Before inoculation, sewage samples were incubated with different concentrations of trypsin (from 0 to $50 \mu \mathrm{g} / \mathrm{ml}$ ) for different times (from $0 \mathrm{~min}$ to $2 \mathrm{~h})$ at $37^{\circ} \mathrm{C}$. Among 80 samples isolated in $\mathrm{RD}$ cells, only 2 were positive (Table II) in contrast to 43 positive samples in Caco-2 cells (Table III). The probability of isolation in $\mathrm{RD}$ cells $(\mathrm{P}=0.025)$ was 20 times lower that in Caco- 2 cells $(\mathrm{P}=0.538)$. The processing of samples before inoculation (different concentrations of trypsin and different incubation times) did not significantly influence on the isolation of enterovirus strains in RD and Caco-2 cells. There was no significant difference between incubation time and concentration of trypsin and positive results of isolation.

All samples demonstrating characteristic cytopathic effect were positive in Pan-enterovirus RT-PCR. Thus, it confirmed that observing cytopathic effect was connected with the presence of enterovirus.

\section{Discussion}

There is currently no cell line that supports the growth of all enterovirus serotypes. Different cell lines such as HEL, Caco-2, RD, HEp2, A549, and buffalo green monkey kidney cells (BGMK) are used for isolation of enteroviruses (Schmidt et al., 1975; Kok et al., 1998; Buxbaum etal., 2001; Otero etal., 2001; Buck et al., 2002). In this study, Caco-2 cell line was used for isolation of enteroviruses from sewage and cerebrospinal samples. In addition to Caco-2 cells, samples were also evaluated by RT-PCR assay for the presence of enteroviruses, and isolated in RD cells. Caco- 2 cells were more effective in enterovirus isolation than $\mathrm{RD}$ cells. The rates of enterovirus isolation for 32 samples of cerebrospinal fluid positive in RT-PCR assay were $68.75 \%$ by Caco- 2 cells, in contrast to $31.25 \%$ by RD cells. The high viral titre in clinical specimen (intensive band after PCR reaction) resulted in rate increase for isolation in Caco- 2 cells and RD cells ( $87.5 \%$ and $50 \%$, respectively). 
Also, the probability of isolation of enteroviruses from sewage in Caco- 2 cells was 20 times higher that in $\mathrm{RD}$ cells. All positive isolations in Caco- 2 cells were observed in the first passage; it was impossible in $\mathrm{RD}$ cells. In the case of RD cells, all positive isolations were observed in the second passage. The cell culture of Caco- 2 cells after inoculation was in good condition for several days in contrast to RD cell culture. RD cells showed rapid degeneration due to non-specific toxicity of the specimen (sewage). Negative results of isolation in $\mathrm{RD}$ cells are probably a consequence of the presence of compounds that are toxic for cells. The presence of factors such as metals, humic acids, and other organic matter can interfere with cell growth. Toxic or inhibitory compounds which can impair the sensitivity of cell culture and molecular systems are found frequently in environmental samples (Murrin and Slade 1997; Reynolds et al., 1996). Toxicity in cell culture can be variable; excessive toxicity causes widespread cell death while limited toxicity may adversely affect virus attachment to cells.

It is interesting to note that in a study by Reigel (1985), different viruses from clinical material replicated in Caco-2 cells: enteroviruses (coxsackieviruses B1-B6, poliovirus types 1-3, most echoviruses and coxsackieviruses A), adenoviruses, herpes simplex virus types 1 and 2, measles viruses, respiratory syncytial viruses, parainfluenza type 2 viruses, and to a lesser extent rubella and mumps viruses. However, Caco-2 cells are not popular in environmental analysis. Our study demonstrates that the resistance of Caco-2 cells for cytotoxic components from sewage is of crucial importance. It should also be considered that in years with high activity of types growing well in cell culture, the sensitivity of cell culture can be higher than in years with lower enterovirus activity (Roth et al., 2007).

The addition of trypsin does not affect enterovirus isolation. The proteolytic enzymes have been reported to have several effects on cell cultures and virus cultivation. Enzyme treatment enhanced infectivity in most enteric viruses, for example in reoviruses (Rutjes et al., 2009). Trypsin treatment is not recommended in enterovirus isolation. That enzyme can cleave some enterovirus capsid protein, but usually does not affect infectivity.

The high probability of enteroviruses' isolation in Caco-2 cells in our study demonstrates that sewage testing may be very useful in epidemiological study of enteroviruses circulating in the population. Sewage surveillance system has been shown to be more sensitive than reporting of clinical cases of serious illness in a community (Sinclair et al., 2008; Bosch et al., 2008). Data regarding the occurrence of viruses in raw sewage may provide an overview of the epidemiology of virus infections circulating in the community, and at the same time may reveal the occurrence of asymptomatic infections (Pinto et al., 2007; Lodder et al., 2012). The usefulness of community sewage testing to monitor the presence of polioviruses in the face of the circulation of wild-type poliovirus in the community has been demonstrated in the Netherlands (Van der Avoort et al., 1995) and Finland (Poyry et al., 1988), and similar testing of sewage may be useful for the monitoring of echoviruses and coxsackieviruses.

In conclusion, using Caco-2 cells for virus isolation in sewage seems to be very promising for environmental surveillance of enterovirus circulation and epidemiology, with all the significant effects that this may have on public health. Therefore, it is always important to consider the limitations imposed by the toxicity of environmental samples when selecting cells for viral isolation. Also, the isolation of enterovirus strains from clinical material (e.g. cerebrospinal fluids) with the use of Caco-2 cells seems to be very promising.

\section{Acknowledgments}

This study was supported by Ministry of Science and Higher Education of Poland grant NN 404113839.

\section{Literature}

Bosch A., S. Guix, D. Sano and R.M. Pinto. 2008. New tools for the study and direct surveillance of viral pathogens in water. Curr. Opin. Biotechnol. 19: 295-301.

Buck G.E., M. Wiesemann and L. Stewart. 2002. Comparison of mixed cell culture containing genetically engineered BGMK and CaCo-2 cells (Super E-Mix) with RT-PCR and conventional cell culture for the diagnosis of enterovirus meningitis. J. Clin. Virol. 25: S13-S18.

Buxbaum S., A. Berger, W. Preiser, H.F. Rabenau and H.W. Doerr. 2001. Enterovirus infections in Germany: comparative evaluation of different laboratory diagnostic methods. Infection. 29: 138-142.

Hamza I.A., L. Jurzik, K. Uberla and M. Wilhelm. 2011. Methods to detect infectious human enteric viruses in environmental water samples. Int. J. Hyg. Environ. Health. 214: 424-436.

Kok T.W., T. Pryor and L. Payne. 1998. Comparison of rhabdomyosarcoma, buffalo green monkey kidney epithelial, A549 (human lung epithelial) cells and human embryonic lung fibroblasts for isolation of enteroviruses from clinical samples. J. Clin. Virol. 11: 61-65.

Lipson S.M., R. Walderman, P. Costello and K. Szabo. 1988. Sensitivity of rhabdomyosarcoma and guinea pig embryo cell cultures to field isolates of difficult-to-cultivate group A coxsackieviruses. J. Clin. Microbiol. 26: 1298-1303.

Lodder W.J., A.M. Buisman, S.A. Rutjes, J.C. Heijne, P.F. Teunis and A.M. de Roda Husman. 2012. Feasibility of quantitative environmental surveillance in poliovirus eradication strategies. Appl. Environ. Microbiol. 78: 3800-3805.

Murrin K. and J. Slade. 1997. Rapid detection of viable enteroviruses in water by tissue culture and semi-nested polymerase chain reaction. Water Sci. Technol. 35: 429-432

Otero J.R., L. Folgueira, G. Trallero, C. Prieto, S. Maldonado, M.J. Babiano and I. Martinez-Alonso. 2001. A-549 is a suitable cell line for primary isolation of coxsackie B viruses. J. Med. Virol. 65: $534-536$ 
Pinto R.M., D. Alegre, A. Dominguez, W.M. El-Senousy, G. Sanchez, C. Villena, M.I. Costafreda, L. Aragones and A. Bosch. 2007. Hepatitis A virus in urban sewage from two Mediterranean countries. Epidemiol. Infect. 135: 270-273.

Pinto R.M., R. Gajardo, F.X. Abad, and A. Bosch. 1995. Detection of fastidious infectious enteric viruses in water. Environ. Sci. Technol. 29: 2636-2638.

Poyry T., M. Stenvik and T. Hovi. 1988. Viruses in sewage waters during and after a poliomyelitis outbreak and subsequent nationwide oral poliovirus vaccination campaign in Finland. Appl. Environ. Microbiol. 54: 371-374.

Reigel F. 1985. Isolation of human pathogenic viruses from clinical material on CaCo2 cells. J. Virol. Methods. 12: 323-327.

Reynolds K.A., C.P. Gerba and I.L. Pepper. 1996. Detection of infectious enteroviruses by an integrated cell culture-PCR procedure. Appl. Environ. Microbiol. 62: 1424-1427.

Roth B., M. Enders, A. Arents, A. Pfitzner and E. TerletskaiaLadwig. 2007. Epidemiologic aspects and laboratory features of enterovirus infections in Western Germany, 2000-2005. J. Med. Virol. 79: 956-962.

Rutjes S.A., W.J. Lodder, A.D. van Leeuwen and A.M. de Roda Husman. 2009. Detection of infectious rotavirus in naturally contaminated source waters for drinking water production. J. Appl. Microbiol. 107: 97-105.

Schmidt N.J., H.H. Ho and E.H. Lennette. 1975. Propagation and isolation of group A coxsackieviruses in RD cells. J. Clin. Microbiol. 2: $183-185$.

Sedmak G., D. Bina, J. Macdonald and L. Couillard. 2005. Nine-year study of the occurrence of culturable viruses in source water for two drinking water treatment plants and the influent and effluent of a Wastewater Treatment Plant in Milwaukee, Wisconsin (August 1994 through July 2003). Appl. Environ. Microbiol. 71: 1042-1050.

Sinclair R.G., C.Y. Choi, M.R. Riley and C.P. Gerba. 2008. Pathogen surveillance through monitoring of sewer systems. Adv. Appl. Microbiol. 65: 249-269.

Tapparel C., F. Siegrist, T.J. Petty and L. Kaiser. 2013. Picornavirus and enterovirus diversity with associated human diseases. Infect. Genet. Evol. 14: 282-293.

Terletskaia-Ladwig E., S. Meier, R. Hahn, M. Leinmuller, F. Scheider, and M. Enders. 2008. A convenient rapid culture assay for the detection of enteroviruses in clinical samples: comparison with conventional cell culture and RT-PCR. J. Med. Microbiol. 57: 1000-1006.

Van der Avoort H., J. Reimerink, A. Ras, M. Muldres and A. van Loon. 1995. Isolation of epidemic poliovirus from sewage during the 1992-3 type 3 outbreak in The Netherlands. Epidemiol. Infect. 114: 481-491.

WHO. 2004. Polio laboratory manual. WHO/IVB/04.10. World Health Organization, Geneva, Switzerland.

Witek A., M. Brzóstkowska, A. Diuwe and M. Wieczorek. 2011. Identification of infection agent in diagnostic material from patients with suspicion of enteroviral meningitis (in Polish). Przegl. Epidemiol. 65:557-560.

Zurbriggen S., K. Tobler, C. Abril, S. Diedrich, M. Ackermann, M.A. Pallansch and A. Metzler. 2008. Isolation of sabin-like polioviruses from wastewater in a country using inactivated polio vaccine. Appl. Environ. Microbiol. 74: 5608-5614. 
